\title{
Chlamydiainfeksjon i Sør-Trøndelag - behandling og oppfølging
}

\author{
Sammendrag \\ Bakgrunn. I henhold til norske ret- \\ ningslinjer skal infeksjoner forårsaket \\ av Chlamydia trachomatis behandles \\ raskt med antibiotika, og kontrollprøve \\ skal tilbys 5-6 uker etter endt behand- \\ ling. Vi har undersøkt utlevering av anti- \\ biotika og bruk av kontrollprøver for \\ kvinner og menn testet for Chlamydia \\ i Sør-Trøndelag i perioden 2004-06.
}

Materiale og metode. Data om alle chlamydiaprøver tatt hos kvinner og menn i alderen 15-59 år bosatt i SørTrøndelag ble hentet fra databasen ved Avdeling for medisinsk mikrobiologi, St. Olavs hospital. Data om antibiotika utlevert fra apotek ble hentet fra Reseptbasert legemiddelregister, Nasjonalt folkehelseinstitutt.

Resultater. I alt 3127 personer var positive for Chlamydia i perioden $18,5 \%$ av 36 590). Av dem med positiv prøve hentet $87 \%$ (1 681/1 920) av kvinnene og $74 \%$ (909/1 207) av mennene ut antibiotika innen fire uker etter at prøven var analysert. Gjennomsnittlig tid fra laboratoriediagnostisering til uttak av medikament var 13,1 dager $195 \% \mathrm{KI}$ 12,7-13,5 dager). Av dem som hentet ut antibiotika, tok $41 \%(689 / 1681)$ av kvinnene og $27 \%$ (247/909) av mennene en kontrollprøve i løpet av perioden 4-16 uker etter uttak av medikamentet.

Fortolkning. Retningslinjene for behandling og oppfølging av dem med positiv chlamydiaprøve etterleves i liten grad, spesielt gjelder det menn.

\section{Sara Ghaderi*}

Fakultet for informasjonsteknologi, matematikk og elektroteknikk Norges teknisk-naturvitenskapelige universitet

\section{Svein Arne Nordbø}

Avdeling for medisinsk mikrobiologi St. Olavs hospital

og

Institutt for laboratoriemedisin,

barne- og kvinnesykdommer

Norges teknisk-naturvitenskapelige universitet

Inger Johanne Bakken*

inger.johannebakken@helsedir.no

Avdeling for forebyggende helsearbeid

SINTEF Teknologi og samfunn

7465 Trondheim

* Nåværende adresser:

S. Ghaderi, Institutt for samfunnsmedisinske fag Universitetet i Bergen

I.J. Bakken, Avdeling Norsk pasientregister Helsedirektoratet

Postboks 6173 Sluppen

7437 Trondheim

Infeksjoner forårsaket av Chlamydia trachomatis er som regel asymptomatiske. Screening og smitteoppsporing er derfor viktige tiltak for å hindre spredning. I henhold til de norske retningslinjene skal personer med påvist chlamydiainfeksjon behandles med antibiotika, enten azitromycin i engangsdose eller tetrasyklin i sju dager. Amoksicillin anbefales ved graviditet. Videre skal alle med positiv chlamydiatest tilbys kontrollprøve 5-6 uker etter avsluttet behandling.

Eneste laboratorium for analyse av chlamydiaprøver i Sør-Trøndelag er det ved St. Olavs hospital. Vi har tidligere benyttet oss av laboratoriedata derfra til å gjennomføre populasjonsbaserte studier av prøvetakingsatferd og prevalens av Chlamydia $(1,2)$.

Reseptbasert legemiddelregister ved Nasjonalt folkehelseinstitutt (Reseptregisteret) ble opprettet 1.1. 2004 som ledd i arbeidet med å optimalisere legemiddelbruken i befolkningen (3). Registeret mottar månedlig opplysninger fra alle apoteker om utlevering av reseptpliktige legemidler til pasienter, leger og institusjoner.

Målet med foreliggende studie var å undersøke uttak av antibiotika og omfanget av kontrollprøver hos personer med påvist chlamydiainfeksjon. Det ble gjort gjennom kobling av data fra St. Olavs hospital og data fra Reseptregisteret. Begge disse kildene inneholder komplett informasjon om hele populasjonen. Etter hva vi kjenner til, er det ikke blitt gjennomført tilsvarende studier i Norge tidligere.

\section{Materiale og metode}

Studien omfatter personer med chlamydiaprøve analysert ved Avdeling for medisinsk mikrobiologi ved St. Olavs hospital (laboratoriedatabasen) i perioden 1.1. 2004-31.12. 2006. Informasjon om alle uttak av antibiotika fra norske apoteker (definert ved ATCkode J01) i inntil to måneder etter at prøven var analysert ble hentet fra reseptregisteret.

Dataene fra St. Olavs hospital besto av informasjon om fødselsnummer, hjemstedsfylke, dato for prøvetaking, prøvemateriale og analyseresultat, som beskrevet tidligere (1). Dataene fra Reseptregisteret var fødselsnummer (pseudonymisert), dato for uttak, type medikament og dosering. Koblingen av data ble gjort mulig ved at fødselsnumrene i laboratoriedatabasen ble pseudonymisert etter samme nøkkel som fødselsnumrene som inngår i Reseptregisteret.

I løpet av studieperioden ble 58048 prøver analysert for Chlamydia. Vi ekskluderte prøver fra samme person innenfor 30 dager der begge var prøver negative $(n=534)$ og prøver som ble analysert samme dag $(n=730)$. Deretter ekskluderte vi prøver for kvinner og menn som var hjemmehørende utenfor Sør-Trøndelag $(\mathrm{n}=12279)$, prøver for dem under 15 år $(n=204)$ og prøver for dem som var 60 år og eldre $(\mathrm{n}=335) .324$ prøveresultater registrert med ugyldig fødselsnummer ble ekskludert. Vi sto da igjen med data for 43642 prøver.

Vi begrenset studiematerialet til første prøve per år for hvert individ $(\mathrm{N}=36590)$. For personer med positiv chlamydiaprøve beregnet vi andel med uttak av antibiotika etter kjønn og alder. Vi skilte mellom azitromycin og andre antibiotika. Tid til behandling ble beregnet som antall dager fra laboratoriediagnostisering til uttak av medikament. Videre beregnet vi for personer med uttak av antibio-

\section{Hovedbudskap}

- En stor andel av dem med påvist chlamydiainfeksjon forblir ubehandlet

- Anbefalingene om kontrollprøve etter endt behandling etterleves i liten grad

- I det forebyggende arbeidet bør man konsentrere seg mer om dem med påvist chlamydiainfeksjon 
Tabell 1 Uttak av antibiotika ved apotek (data fra reseptregisteret) innen fire uker fra laboratoriediagnostisering av Chlamydia i Sør-Trøndelag i årene 2004-06

\begin{tabular}{lcccc} 
Alder lår) & $\begin{array}{c}\text { Antall med positiv } \\
\text { chlamydiaprøve }\end{array}$ & Ingen antibiotika (\%) & Azitromycin (\%) & Annen antibiotika (\%) \\
\hline Kvinner & 659 & 11,7 & 83,2 & 5,2 \\
\hline $15-19$ & 793 & 13,7 & 78,4 & 7,8 \\
\hline $20-24$ & 278 & 10,1 & 80,2 & 9,7 \\
\hline $25-29$ & 190 & 13,2 & 78,4 & 8,4 \\
\hline $30-59$ & 1920 & 12,4 & 80,3 & 7,2 \\
\hline Totalt & & & & \\
\hline Menn & 167 & 25,7 & 71,9 & 2,4 \\
\hline $15-19$ & 511 & 25,4 & 68,9 & 5,7 \\
\hline $20-24$ & 281 & 24,2 & 71,9 & 3,9 \\
\hline $25-29$ & 248 & 23,0 & 73,0 & 4,0 \\
\hline $30-59$ & 1207 & 24,7 & 70,8 & 4,5 \\
\hline Totalt & & & & \\
\hline
\end{tabular}

Tabell 2 Andel (\%) kontrollprøver hos kvinner og menn med uttak av antibiotika etter påvist chlamydiainfeksjon i årene 2004-06 ( N = 2590)

\begin{tabular}{|ccccc} 
Alder lår) & $\begin{array}{c}\text { Antall med uttak } \\
\text { avantibiotika }\end{array}$ & $\begin{array}{c}\text { Kontrollprøve } \\
\text { i perioden 1-4 uker } \\
\text { etter laboratoriedia- } \\
\text { gnostisering (\%) }\end{array}$ & $\begin{array}{c}\text { Kontrollprøve } \\
\text { i perioden 4-16 uker } \\
\text { etter laboratoriedia- } \\
\text { gnostisering (\%) }\end{array}$ & $\begin{array}{c}\text { Ingen kontroll- } \\
\text { prøve (\%) }\end{array}$ \\
\hline Kvinner & 582 & 17,9 & 47,9 & 34,2 \\
\hline $15-19$ & 684 & 25,1 & 37,4 & 37,5 \\
\hline $20-24$ & 250 & 22,8 & 35,6 & 41,6 \\
\hline $25-29$ & 165 & 23,6 & 40,0 & 36,4 \\
\hline $30-59$ & 1681 & 22,1 & 41,0 & 36,9 \\
\hline Totalt & 124 & & & 57,2 \\
\hline Menn & 381 & 10,5 & 32,3 & 55,9 \\
\hline $15-19$ & 213 & 16,3 & 27,8 & 57,3 \\
\hline $20-24$ & 191 & 18,3 & 24,4 & 53,9 \\
\hline $25-29$ & 909 & 20,4 & 25,7 & 56,0 \\
\hline $30-59$ & & 16,8 & 27,2 & \\
\hline Totalt & & & & \\
\hline
\end{tabular}

tika andel med kontrollprøve innen 16 uker fra uttak. Tid til kontrollprøve er antall uker fra uttak av medikament til kontrollprøve.

Alle analyser er gjennomført ved hjelp av SPSS for Windows (versjon 17.0). KaplanMeiers metode ble benyttet for estimering av gjennomsnittlig tid til behandling.

Studien er anbefalt av regional komité for medisinsk og helsefaglig forskningsetikk, Midt-Norge. Helsedirektoratet og Datatilsynet har gitt de nødvendige tillatelser.

\section{Resultater}

I alt 3127 personer var positive for Chlamydia $(8,5 \%$ av 36590$)$.

Av alle med positiv chlamydiaprøve hentet $76,6 \%$ ut azitromycin ved apotek innen fire uker etter at prøven var analysert. 6,2\% hentet ut annen antibiotika. Andelen menn som ikke hentet ut antibiotika, var om lag dobbelt så høy som tilsvarende andel for kvinner (tab 1).

\section{Diskusjon}

All chlamydiapåvisning i Sør-Trøndelag utføres ved St. Olavs hospital, og siden vi har ekskludert data fra personer bosatt utenfor fylket og har komplette data om uttak av antibiotika, er dette en populasjonsbasert studie av behandling av Chlamydia.

I henhold til de norske retningslinjene skal personer med påvist chlamydiainfeksjon behandles med antibiotika umiddelbart. En kontrollprøve bør tas først 5-6 uker etter avsluttet behandling, da nukleinsyretesten også kan påvise døde bakterier og gi et falskt positivt svar dersom kontrollprøven blir tatt for tidlig (4).

\section{Behandling}

Studien viser at i overkant av tre firedeler av de chlamydiapositive tok ut azitromycin ved apotek innen fire uker etter laboratoriediagnostiseringen. En mindre andel tok ut annen antibiotika. For én av åtte kvinner og én av fire menn med positiv prøve ble det ikke registrert noe uttak av antibiotika. Dette viser etter vår mening at det er en betydelig grad av behandlingssvikt for denne pasientgruppen. Tiden til behandling kan dessuten virke noe lang, da det gjennomsnittlig gikk nesten to uker fra laboratoriediagnostiseringen til medikamentet ble hentet ut.

Nasjonale overvåkingstall viser at det har vært en økning både i antall tester og i antall påviste chlamydiatilfeller (5). I det forebyggende arbeidet har man i stor grad lagt vekt på å få folk til å teste seg for Chlamydia ved partnerbytte. Våre data tyder imidlertid på at det også er viktig å følge opp dem som tester positivt. Det at andelen med påvist infeksjon som ikke tar ut antibiotika er så høy, kan tyde på at informasjonen som ble gitt $\mathrm{i}$ forbindelse med prøvetakingen ofte var mangelfull eller lite tilpasset mottakeren. Våre data gir ikke informasjon om årsaken til at det ble tatt prøve, men det virker sannsynlig at behandlingssvikten er høyere blant dem som ikke har hatt symptomer i forkant av prøvetakingen. En mulig feilkilde $\mathrm{i}$ vårt datamateriale er at vi ikke har informasjon om bruken av dobbeltresept for azitromycin. Det er derfor tenkelig at noen av dem med påvist infeksjon har fått azitromycin fra en chlamydiapositiv partner.

Våre data tyder videre på at presumptiv behandling for chlamydiainfeksjon er relativt lite brukt, da kun 1,5\% av dem med negativ chlamydiaprøve hentet ut azitromycin. Det er imidlertid verdt å merke seg at disse utgjør en nokså stor andel av alle dem som ble behandlet med azitromycin i studieperioden (om lag én av seks). Studien gir ikke informasjon om uttak av azitromycin ved mistanke om chlamydiainfeksjon hvis prøve ikke ble tatt.

\section{Kontrollprøve}

Kun fire av ti kvinner og en firedel av mennene behandlet for Chlamydia var registrert med en kontrollprøve i perioden 4-16 uker etter uttak av medikament. I en tidligere 
tverrsnittsundersøkelse blant unge menn i Trondheim og Oslo fant vi at bare halvparten av dem som ble behandlet for Chlamydia møtte for kontrollprøve, til tross for gjentatte oppfordringer (6). Både i foreliggende studie og i tverrsnittsundersøkelsen var om lag en tidel av kontrollprøvene positive, noe som viser at det er viktig å få tatt en slik.

\section{Konklusjon}

Registerkobling kan gi ny informasjon om behandling og oppfølging ved seksuelt overførbar sykdom. Retningslinjene fra norske helsemyndigheter ved påvist chlamydiainfeksjon etterleves $\mathrm{i}$ for liten grad. Det er alarmende at en stor andel av dem med posi- tiv prøve ikke henter ut medikament for behandling av infeksjonen og at bruken av adekvat kontrollprøve er så lav. Tettere oppfølging av dem med påvist chlamydiainfeksjon vil styrke det forebyggende arbeidet.

Oppgitte interessekonflikter: Ingen

\section{Litteratur}

1. Bakken IJ, Nordbø SA, Skjeldestad FE. Chlamydia trachomatis testing patterns and prevalence of genital chlamydial infection among young men and women in central Norway 1990-2003: a population-based registry study. Sex Transm Dis 2006; 33: $26-30$.

2. Bakken IJ, Nordbø SA. Chlamydiainfeksjon i SørTrøndelag - prøvetaking og prevalens. Tidsskr Nor Lægeforen 2007; 127: 3202-5.
3. Strøm H. Reseptbasert legemiddelregister: et viktig verktøy for å oppnå detaljert legemiddelstatistikk. Norsk epidemiologi 2004; 14: $53-5$.

4. Chlamydiainfeksjon (genital). Smittevernboka. www.fhi.no (17.10.2010).

5. Kløvstad H, Aavitsland P. Chlamydia trachomatis infections in Norway, 1986 to 2006, surveillance data. Sex Transm Dis 2009; 36: 17-21.

6. Bakken IJ, Skjeldestad FE, Halvorsen TF. Norwegian men diagnosed with genital Chlamydia trachomatis infection notified two-thirds of their sexual partners. Scand J Infect Dis 2008; 40: $275-8$

Mottatt 24.3. 2010, første revisjon innsendt 24.5 2010, godkjent 4.11. 2010. Medisinsk redaktør Trine B. Haugen. 